\title{
Retrospective Study of Nd:YAG Capsulotomy Following Phacoemulsification
}

\author{
P. Hegde ${ }^{1}$, S. Ganesh 2 , S. Brar ${ }^{3}$ \\ ${ }^{1}$ Department of Ophthalmology, Nethradhama Superspeciality Eye Hospital, Bangalore, Karnataka, India. \\ ${ }^{2}$ Department of Ophthalmology, Nethradhama Superspeciality Eye Hospital, Bangalore, Karnataka, India. \\ ${ }^{3}$ Department of Ophthalmology, Nethradhama Superspeciality Eye Hospital, Bangalore, Karnataka, India.
}

\section{ABSTRACT}

\section{BACKGROUND}

Posterior Capsular Opacification (PCO) or After Cataract is one of the most common delayed postoperative complications of uncomplicated phacoemulsification cataract surgery, which occurs due to the migration of lens epithelial cells (LECs) on the posterior capsule. PCO is primarily treated by Nd:YAG capsulotomy which involves creating an opening in the posterior capsule, thereby improving vision. Our aim was to evaluate the incidence of Posterior Capsular Opacification (PCO) in different types of foldable IOLs and also to estimate the duration between phacoemulsification surgery and PCO formation requiring Nd:YAG capsulotomy.

\section{METHODS}

This retrospective study included all patients who had undergone Nd:YAG capsulotomy after uncomplicated phacoemulsification surgery with foldable IOL implantation in the past 5 years. Thirteen types of acrylic foldable IOLs were analysed for the incidence and time taken for PCO formation after phacoemulsification surgery.

\section{RESULTS}

A total of 28149 eyes of 27779 patients, with mean age of $69 \pm 7.27$ years, underwent uncomplicated phacoemulsification with foldable IOL implantation during the study period. 1.3\% (354) eyes of 182 males and 162 females underwent Nd:YAG capsulotomy for clinically significant PCO. The overall incidence of hydrophobic and hydrophilic IOLs showing PCO formation was $0.73 \%$ and $2.4 \%$ respectively, the difference being statistically significant $(\mathrm{p}=0.042)$. Individually, the IOL with the highest incidence of PCO formation was SENSAR, 3.75\% (AR40e) followed by ULTIMA, 3.47\% (ULTIMA AC) while SENSAR-1 (AABO0) and Tecnis1 (ZCBO0) had the lowest incidence of PCO. PCO was seen significantly higher in square edge optic designs compared with round edge $(\mathrm{p}=0.017)$, while there was no statistically significant difference between single- and three-piece designs $(\mathrm{p}=0.21)$. PCO was significantly higher in IOLs with optic diameter of $6 \mathrm{~mm}$ when compared to $5.5 \mathrm{~mm}$ $(p=0.016)$. The average duration between phacoemulsification surgery and Nd:YAG capsulotomy was $32 \pm 3$ months, the duration being significantly less for hydrophilic ( $27 \pm 4$ months) than hydrophobic $(35 \pm 3$ months) $(\mathrm{p}=0.041)$.

\section{CONCLUSIONS}

The incidence of PCO formation was more and earlier with hydrophilic than with hydrophobic IOLs. It was more frequently seen with square edge optic design. However, lens design, single-piece or three-piece did not seem to influence the rate of PCO formation.

\section{KEY WORDS}

Posterior Capsular Opacification (PCO), Hydrophilic and Hydrophobic Intraocular Lenses (IOLs)

\author{
Corresponding Author: \\ Dr. Puneet Hegde, \\ Flat No. 403, Haribhakthi Apts., \\ Pintos Lane, Mangalore-575004, \\ Karnataka, India. \\ E-mail: drpuneethegde@gmail.com
}

DOI: $10.14260 / \mathrm{jemds} / 2019 / 718$

Financial or Other Competing Interests: None.

How to Cite This Article:

Hegde P, Ganesh S, Brar S. Retrospective study of Nd:YAG capsulotomy following phacoemulsification. J. Evolution Med. Dent. Sci. 2019;8(44):3309-3313, DOI: $10.14260 /$ jemds $/ 2019 / 718$

Submission 06-09-2019,

Peer Review 19-10-2019,

Acceptance 26-10-2019,

Published 04-11-2019.

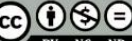




\section{BACKGROUND}

Secondary cataract, also known as posterior capsule opacification (PCO), is the most common complication after cataract surgery, resulting from migration and proliferation of residual lens epithelial cells (LECs) on to the central posterior capsule, leading to decrease in visual function. The incidence of PCO has been estimated to be between $18 \%$ to $50 \%$ in various studies.1,2,3 The treatment of PCO is typically neodymium yttrium-aluminium-garnet (Nd:YAG) laser posterior capsulotomy. Currently the most commonly used IOLs in practice are the hydrophobic acrylic Intraocular Lenses (IOLs). ${ }^{2}$ These polymers of acrylate are foldable under room temperature, have very low water content and a high refractive index. They unfold in a controlled fashion and have been shown to have capsular biocompatibility. On the other hand, hydrophilic acrylic lenses belong to a heterogeneous material group and have a high water content. These lenses are cut in the dehydrated state and then hydrated and stored in solution. The water content between IOLs varies widely and can be as high as $38 \% .4,5$

Hydrophobic material lenses have been reported to have low rates of PCO compared to hydrophilic materials.(6) It was proposed that bio adhesive nature of hydrophobic acrylic IOLs may account for its reduced PCO formation by helping it adhere to the capsule and sequestering the IOL in the bag. ${ }^{6}$ Various other properties of IOLs are also known to play role in PCO formation. The IOLs with square edge optic create a sharp bend in the posterior capsule that mechanically inhibits the cell migration to the posterior capsule where as IOLs with round edge optics are unable to create such bend, thus, losing their effectiveness to prevent the PCO formation. ${ }^{6}$ Hence, PCO formation was shown to be low with square compared to round optic lens. ${ }^{7}$ Large IOL optic was also shown to be associated with less PCO.8,9,10 On the basis of contact inhibition, recently, the consensus has been made that the relationship between the IOL optic and the anterior capsule plays an integral role in PCO development. ${ }^{10}$

Different practical approaches to prevent PCO formation have been suggested, however the exact mechanism of PCO formation has not yet been established. At present, the IOL optic design and lens material are the important factors that are known to play a role in occurrence of PCO. Previous studies have mainly analysed and compared occurrence of PCO in hydrophobic versus hydrophilic, silicon versus PMMA versus acrylic, square edge versus round edge and single-piece versus three-piece models of intraocular lenses. ${ }^{9,10}$ However, the aim of the present study was to perform an overall review of incidence of PCO leading to YAG capsulotomy in a high volume cataract surgery centre and comparing different types of foldable lenses in terms of their incidence, duration and various properties such as material, type, design and size in a large retrospective case series.

\section{METHODS}

This was a retrospective study involving all patients who had undergone Nd:YAG capsulotomy after uncomplicated phacoemulsification surgery with foldable IOL implantation in our institution from $1^{\text {st }}$ Jan 2009 to $31^{\text {st }}$ Dec 2013. All surgeries were performed by 3 experienced cataract surgeons who followed standard surgical technique for phacoemulsification.

The inclusion criteria were age $>40$ years, uncomplicated phacoemulsification, Continuous Curvilinear Capsulorrhexis (CCC), in the bag foldable IOL implantation, absence of primary PCO and PCO causing clinically significant diminution of vision, grade 2 and above with TETZ PCO grading system Patients who had coexisting conditions such as uncontrolled diabetes, pseudoexfoliation, uveitis and trauma, which are known to accelerate the process of PCO formation were excluded from the study. We also excluded eyes with coexisting glaucoma, corneal or retinal pathology and multifocal IOL implants.

The degree of opacification was assessed using distant direct ophthalmoscopy, direct visualization by slit lamp and a decrease in BCVA after surgery PCO was graded as per the TETZ PCO scoring system and eyes with grade 2 and above were advised to undergo YAG capsulotomy. ${ }^{11}$ Clinically significant PCO was defined as a reduction in BCVA of more than 2 lines in Snellen's visual acuity chart. ${ }^{11}$ An informed consent was obtained from all patients before the procedure was performed. Pupil was dilated using mydriatics (Itrop plusCipla, Solan- Himachal Pradesh).

\section{Procedure of YAG Capsulotomy}

The equipment used was Zeiss Visulas 3 Nd:YAG laser with a frequency of $1064 \mathrm{~nm}$, spot size of 50 microns and power range from 1 to $2 \mathrm{~mJ}$. The laser was delivered through a slit lamp. Eye was anaesthetized using topical $0.5 \%$ proparacaine (Paracaine- Sunways, Ahmedabad). Patients chin was positioned on the chin rest and forehead touched to the head rest. The patient was instructed to fixate on the illuminated fixation target. The machine is set to posterior offset. This was followed by delivery of laser with the laser shots being placed along the tension lines on the posterior capsule. A cruciate opening, beginning at 12 o clock in the periphery and progressing towards the 6 ' 0 ' clock position, followed by cutting across from 3 to 9 o clock position was made. The size of capsulotomy aimed was 4 to $6 \mathrm{~mm}$ depending on pupillary dilatation. Any residual tags were removed, and free-floating fragments avoided. Post procedure, antibiotic steroid eye drops (Oflacin DX - Microlabs Limited.) were prescribed for 4 times a day for one week. No intra operative complications occurred during the procedure for any of the eyes. Post procedure, 4 patients had raised intraocular pressure, which was managed with topical antiglaucoma medications. There were no major complications like hyphema, macular oedema or vitreous in anterior chamber post procedure.

\section{Data Analysis}

Data was analysed using the PASW 17.0 (Predictive Analysis Software) (SPSS Inc, Chicago, Illinois, USA), Chi square test and the paired $t$ test. A $p$ value of $<0.05$ was considered significant. 


\section{RESULTS}

A total of 28149 eyes of 27779 patients, underwent uncomplicated phacoemulsification with foldable IOL implantation during the study period. A total of 354 eyes of 344 patients with mean age of $69 \pm 7.27$ years underwent Nd:YAG capsulotomy of which $182(53 \%)$ were males and $162(47 \%)$ were females. The incidence of Nd:YAG capsulotomy in this series was found to be $1.3 \%$. The incidence of YAG capsulotomy was higher in hydrophilic IOLs compared to hydrophobic IOLs, and the difference was found to be statistically significant. (Table 1). Table 2 enumerates characteristics of the various foldable lenses along with their incidence of YAG capsulotomy. The IOLs with the highest frequency of YAG capsulotomy were SENSAR, (3.75\%, Model AR40e) followed by ULTIMA (3.47\%) and RYCF( $2.4 \%$ ) while SENSAR 1, TECNIS 1 and ACRIOL lenses had the lowest frequency of YAG capsulotomy being $0 \%, 0.15 \%$ and $0.2 \%$ respectively.

\begin{tabular}{|c|c|}
\hline Total number of foldable IOLs implanted & 28149 \\
\hline Number of hydrophobic IOLs implanted & 19441 \\
\hline Number of hydrophilic IOLs implanted & 8708 \\
\hline No. of eyes requiring YAG capsulotomy & $354(1.3 \%)$ \\
\hline No. of hydrophobic IOLs YAGed & $143(0.73 \%)$ \\
\hline p Value & 0.137 \\
\hline No. of hydrophilic IOLs YAGed & $211(2.4 \%)$ \\
\hline p Value & 0.042 \\
\hline Table 1. Details of Foldable IOLs that Required YAG Capsulotomy \\
\hline
\end{tabular}

\begin{tabular}{|c|c|c|c|c|c|c|c|c|c|}
\hline 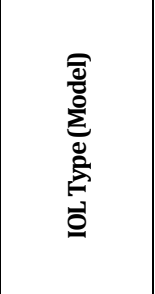 & 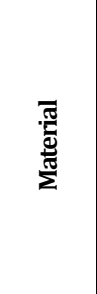 & 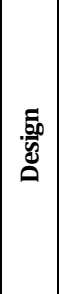 & 兽 & 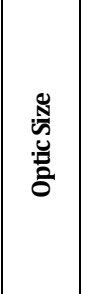 & 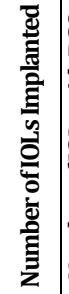 & 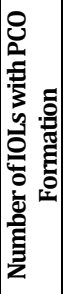 & 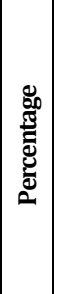 & 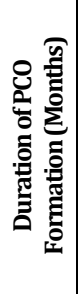 & 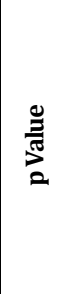 \\
\hline ACRIOL (AS 6) & HPo Acr & \begin{tabular}{|c|}
1 \\
piece
\end{tabular} & $\begin{array}{l}\text { Square } \\
\text { edge }\end{array}$ & $6 \mathrm{~mm}$ & 906 & 2 & 0.2 & $33 \pm 3$ & 0.141 \\
\hline $\begin{array}{l}\text { ACRYSOF } \\
\text { (SN60AT, } \\
\text { SA60AT) }\end{array}$ & HPo Acr & $\begin{array}{c}1 \\
\text { piece }\end{array}$ & $\begin{array}{l}\text { Square } \\
\text { edge }\end{array}$ & $5.5 \mathrm{~mm}$ & 3268 & 8 & 0.25 & $31 \pm 3$ & 0.154 \\
\hline $\begin{array}{l}\text { ACRYSOF IQ } \\
\text { (SN6AD1, } \\
\text { MN6AD1) } \\
\end{array}$ & HPo Acr & $\begin{array}{c}1 \\
\text { piece }\end{array}$ & $\begin{array}{c}\text { Round } \\
\text { interrupted }\end{array}$ & $5.5 \mathrm{~mm}$ & 846 & 2 & 0.23 & $29 \pm 4$ & 0.156 \\
\hline $\begin{array}{c}\text { CLARIFLEX } \\
\text { (CLRFLXA, } \\
\text { CLRFLX B } \\
\text { CLRFLX C) }\end{array}$ & HPo Acr & $\begin{array}{c}3 \\
\text { piece }\end{array}$ & Square & $5.5 \mathrm{~mm}$ & 656 & 6 & 0.9 & $28 \pm 3$ & 0.042 \\
\hline \begin{tabular}{|c|} 
HOYA (PC 60R, \\
PS AF 1)
\end{tabular} & HPo Acr & \begin{tabular}{|c|}
3 \\
piece
\end{tabular} & \begin{tabular}{|c|} 
Round \\
interrupted \\
\end{tabular} & $6 \mathrm{~mm}$ & 2078 & 13 & 0.63 & $28 \pm 4$ & 0.092 \\
\hline RYCF (SQ RYCF) & HPiAcr & $\begin{array}{c}1 \\
\text { piece }\end{array}$ & Square & $6 \mathrm{~mm}$ & 1544 & 37 & 2.4 & $30 \pm 3$ & 0.032 \\
\hline $\begin{array}{c}\text { SENSAR (AR40M } \\
\text { AR40E AR40e) }\end{array}$ & HPo Acr & $\begin{array}{c}3 \\
\text { piece }\end{array}$ & Square & $6 \mathrm{~mm}$ & 2645 & 84 & 3.75 & $35 \pm 3$ & 0.025 \\
\hline $\begin{array}{l}\text { SENSAR 1 } \\
\text { (AABOO) }\end{array}$ & HPo Acr & $\begin{array}{c}1 \\
\text { piece }\end{array}$ & Square & $6 \mathrm{~mm}$ & 3583 & 0 & 0 & - & 0 \\
\hline $\begin{array}{l}\text { TECNIS 1 } \\
\text { (ZCBOO) }\end{array}$ & HPo Acr & $\begin{array}{c}1 \\
\text { piece }\end{array}$ & Square & $6 \mathrm{~mm}$ & 4494 & 7 & 0.15 & $36 \pm 3$ & 0.733 \\
\hline \begin{tabular}{|c|} 
TECNIS ACRYLIC \\
(ZCT400)
\end{tabular} & HPo Acr & $\begin{array}{c}3 \\
\text { piece }\end{array}$ & Square & $6 \mathrm{~mm}$ & 1182 & 26 & 2.2 & $38 \pm 3$ & 0.214 \\
\hline TECNIS CL & HPiAcr & $\begin{array}{c}1 \\
\text { piece } \\
\end{array}$ & Square & $5.5 \mathrm{~mm}$ & 2282 & 18 & 0.79 & $32 \pm 2$ & 0.113 \\
\hline $\begin{array}{c}\text { ULTIMA } \\
\text { (ULTIMA AC) } \\
\end{array}$ & HPi Acr & $\begin{array}{c}1 \\
\text { piece } \\
\end{array}$ & Square & $6 \mathrm{~mm}$ & 1980 & 69 & 3.47 & $28 \pm 3$ & 0.036 \\
\hline \begin{tabular}{|c|} 
ZEISS (CT \\
ASPHINA409M, \\
$509 \mathrm{M} 809 \mathrm{M})$ \\
\end{tabular} & HPiAcr & $\begin{array}{c}1 \\
\text { piece }\end{array}$ & Square & $6 \mathrm{~mm}$ & 2583 & 17 & 0.66 & $29 \pm 3$ & 0.198 \\
\hline \multicolumn{10}{|c|}{$\begin{array}{c}\text { Table 2a. Incidence of PCO Formation in Different IOL Designs } \\
\text { and Materials Studied }\end{array}$} \\
\hline
\end{tabular}

\begin{tabular}{|c|c|c|c|}
\hline IOL Type & $\begin{array}{c}\text { Number of IOL } \\
\text { Implanted }\end{array}$ & $\begin{array}{c}\text { Number of IOL with } \\
\text { PCO Formation }\end{array}$ & $\mathbf{\%}$ \\
\hline ACRYFOLD & 180 & 26 & 14.4 \\
\hline AUROLAB & 23 & 1 & 4.6 \\
\hline CEEON & 2 & 1 & 50 \\
\hline CENTRYFOLD & 6 & 1 & 16.7 \\
\hline NASPRO & 252 & 28 & 11.1 \\
\hline SI 40 & 12 & 4 & 33.3 \\
\hline STAAR & 8 & 3 & 37.5 \\
\hline OCUFLEX & 29 & 1 & 3.5 \\
\hline \multicolumn{3}{|c|}{ Table 2b. IOL Design and PCO Formation } \\
\hline (Note: The IOLs in table 2b have not been used for statistical analysis because of \\
\hline
\end{tabular}

their low numbers $(<500)$ which may give false results)

\begin{tabular}{|c|c|c|c|}
\hline $\begin{array}{c}\text { IOL Type } \\
\text { (Model) }\end{array}$ & $\begin{array}{c}\text { Pre YAG BCVA } \\
\text { (logMAR) }\end{array}$ & $\begin{array}{c}\text { Post YAG BCVA } \\
\text { (logMAR) }\end{array}$ & $\mathbf{p}$ \\
\hline ACRIOL & $0.30 \pm 0.04$ & $0.00 \pm 0.00$ & 0.043 \\
\hline ACRYSOF & $0.25 \pm 0.03$ & $0.00 \pm 0.01$ & 0.069 \\
\hline ACRYSOF IQ & $0.25 \pm 0.01$ & $0.00 \pm 0.01$ & 0.083 \\
\hline CLARIFLEX & $0.20 \pm 0.02$ & $0.10 \pm 0.02$ & 0.101 \\
\hline HOYA & $0.50 \pm 0.01$ & $0.10 \pm 0.00$ & 0.032 \\
\hline RYCF & $0.30 \pm 0.02$ & $0.10 \pm 0.01$ & 0.054 \\
\hline SENSAR & $0.60 \pm 0.01$ & $0.00 \pm 0.01$ & 0.027 \\
\hline TECNIS 1 & $0.80 \pm 0.02$ & $0.00 \pm 0.02$ & 0.010 \\
\hline TECNIS ACRYLIC & $0.50 \pm 0.02$ & $0.10 \pm 0.01$ & 0.038 \\
\hline TECNIS CL & $0.50 \pm 0.01$ & $0.10 \pm 0.02$ & 0.023 \\
\hline ULTIMA & $0.60 \pm 0.03$ & $0.10 \pm 0.03$ & 0.034 \\
\hline ZEISS & $0.50 \pm 0.02$ & $0.00 \pm 0.02$ & 0.022 \\
\hline \multicolumn{2}{|c|}{ Table 3. Visual Outcomes after YAG Capsulotomy } \\
\hline
\end{tabular}

The average duration between phacoemulsification surgery and Nd:YAG capsulotomy was $32 \pm 3$ months, the duration being less for hydrophilic $(27 \pm 4$ months $)$ than hydrophobic ( $35 \pm 3$ months), the duration being statistically significant ( $p$ 0.041) PCO was seen significantly higher in square edge optic designs compared with round edge $(p=0.017)$, while there was no statistically significant difference between single and three-piece designs $(p=0.21)$. PCO was significantly higher in IOLs with optic diameter of 6 $\mathrm{mm}$ when compared to $5.5 \mathrm{~mm}(\mathrm{p}=0.016)$ Table 3 shows the visual outcomes post YAG capsulotomy with various foldable lenses. All models of lenses implanted showed improvement in BCVA post procedure while the improvement was statistically significant in 5 models of hydrophobic and 3 models of hydrophilic foldable lenses.

\section{DISCUSSION}

YAG capsulotomy is the most common and preferred modality to treat PCO, although surgical capsulotomy has also been described.12 Most of the previous studies have compared rates of PCO formation between PMMA, Silicon and acrylic intraocular lenses. ${ }^{13,14}$ However, our study focused mainly on analysis of various models (13 models) of acrylic foldable lenses in terms of PCO formation aNd:YAG capsulotomy. We also analysed the average duration for PCO formation following phacoemulsification with various designs and materials of foldable IOLs implanted and their outcomes following YAG Capsulotomy. Various objective methods have been described in literature for assessment of PCO. However, in this study we used TETZ PCO scoring combined with subjective assessment for estimation of severity of PCO. This is an easy and routinely performed grading system in our setting.

Various studies done previously have established that the incidence of PCO was more in hydrophilic compared to hydrophobic foldable IOLs. ${ }^{15,16,17,18,19}$ Our results were in concordance with these studies as we also found a statistically significant difference in the rate of PCO formation between 
these two materials of foldable IOLs. This may be due to the high water content of hydrophilic IOLs which facilitates lens epithelial cells (LEC) ingrowth.

However, in this study, SENSAR (AR40e) had the maximum incidence of PCO (3.75\%), possibly due to the fact that SENSAR is a 3-piece hydrophobic foldable IOL with rigid haptics, which causes stretching of the posterior capsule. This leads to the appearance of corrugations in the posterior capsule which form channels that lead to the increased migration of LECs and thereby increasing the incidence of PCO in these IOLs. On the other hand, hydrophilic IOLs (ZEISS - CT ASPHINA 409M, 509M, 809M) had a low incidence of PCO in our study, possibly due to its 4-point fixation, thereby obstructing the migration of LECs and decreasing PCO formation. ${ }^{20}$

The square -edge design of the lens has been shown to be associated with less incidence of PCO since it may act as a mechanical barrier to lens epithelial cell migration onto the posterior capsule.21,22,23 Studies have confirmed that the rectangular shape of the IOL rim of hydrophobic IOLs with its sharp edges, in combination with the acrylic material, was the main reason for the reduced formation of PCO. ${ }^{24}$ Optic diameter is also known to influence the formation of PCO, the incidence being lower in IOLs with larger optic diameter. ${ }^{25} \mathrm{On}$ the contrary, we found a higher rate of PCO in square edge lenses and IOLs with larger optic diameter. This may be due to the fact that most of the lenses implanted in the study period had square edge design and large optic diameter $(6 \mathrm{~mm})$, hence leading to statistically significant difference compared to round edge and small optic diameter $(5.5 \mathrm{~mm})$.

Previous studies have not established a strong correlation between lens design and PCO,26,27 although some studies found that three-piece foldable lenses were associated with higher PCO rates compared to single piece. ${ }^{28,29}$ However in this study, lens design did not seem to influence the incidence of PCO formation. The average duration between phacoemulsification surgery and Nd:YAG capsulotomy was found to be $32 \pm 3$ months, the duration being significantly shorter for hydrophilic IOLs compared to hydrophobic IOLs, which was in accordance with studies comparing time taken for PCO formation between hydrophobic and hydrophilic lenses.30,31 YAG capsulotomy may be associated with significant complications as reported in various studies. ${ }^{32}$ However, in this series it was found to be a safe procedure, as suggested by very low complication rate $(0.012 \%)$, most of the complications being short term and managed medically with topical medications.

Previous studies have suggested good visual outcomes in terms of BCVA, functional vision, improvement in contrast and aberrations after YAG capsulotomy. ${ }^{33}$ We also found satisfactory visual outcomes after YAG, as we observed a statistically significant improvement in BCVA following the procedure. However, functional vision, contrast and aberrations could not be evaluated due to retrospective nature of the study and non-availability of respective data. However, this study had some limitations. One limitation of the study was that it we could not account for subjects who were lost to follow up, who underwent YAG elsewhere and who were operated in the last 1 year of the study period. Hence, it was difficult to estimate the true incidence of PCO aNd:YAG capsulotomy in this series.
Another limitation was that we did not consider the influence of anterior or posterior capsule polishing, size of capsulorrhexis and IOL overlap during surgery due to unavailability of this information. These factors may have correlation with PCO formation as suggested in literature. ${ }^{34,35}$ The results of this study reinforce the already known fact that hydrophobic IOLs have low incidence of PCO compared to hydrophilic, and hence should be preferred. Since most of the hydrophobic acrylic IOLs currently available are designed to have a square optic edge, this should be an ideal combination further reducing the chances of PCO. We saw contradictory findings in this study in relation to the optic edge design with the incidence of PCO being significantly higher in square edge compared to round edge design. This may suggest that a square edge may not always offer additional protection against PCO. These results may be of significance since the study involved a large cohort and had a long duration of 5 years. These observations may be investigated further with well-designed randomised comparison studies between hydrophobic acrylic lenses with and without square edge optic design involving large sample size and a longer follow-up.

\section{CONCLUSIONS}

The study showed that the incidence of PCO formation was more and earlier with hydrophilic than with hydrophobic IOLs in view of the bioadhesive nature of the hydrophobic IOLs. Therefore, hydrophobic IOLs are the most preferred IOLs for implantation post phacoemulsification. It was more frequently seen with square edge optic design. However, lens design, single-piece or three-piece did not seem to influence the rate of PCO formation.

\section{REFERENCES}

[1] Zemaitience R, Jasinskas V, Barzdziukas V, et al. Prevention of posterior capsule opacification using different intraocular lens (results of one-year clinical study). Medicina Kaunas 2004;40(8):721-30.

[2] Ursell PG, Spalton DJ, Pande MV, et al. Relationship between intraocular lens biomaterials and posterior capsule opacification. J Cataract Refract Surg 1998;24(3):352-60.

[3] Khanzada MA, Gul S, Dabir SA, et al. Comparative incidence of posterior capsular opacificationin AcrySof and PMMA intraocular lenses. Int J Ophthalmol 2009;2(2):150-3.

[4] Linnola RJ, Sund M, Ylnen R, et al. Adhesion of soluble fibronectin, laminin and collagen type IV to intraocular lens materials. J Cataract Refract Surg 1999;25(11):148691.

[5] Apple DJ, Peng Q, Visessook N, et al. Eradication of posterior capsule opacification: documentation of a marked decrease in Nd: YAG laser posterior capsulotomy rates noted in an analysis of 5416 pseudophakic human eyes obtained postmortem. Ophthalmology 2001;108(3):505-18. 
[6] Boyce JF, Bhermi GS, Spalton DJ, et al. Mathematical modeling of the forces between an intraocular lens and the capsule. J Cataract Refract Surg 2002;28(10):1853-9.

[7] Davison JA. Clinical performance of Alcon SA30AL and SA60AT single-piece acrylic intraocular lenses. J Cataract Refract Surg 2002;28(7):1112-23.

[8] Born CP, Ryan Dk. Effect of intraocular lens optic design on posterior capsular opacification. J Cataract Refract Surg 1990;16(2):188-92.

[9] Farbowitz MA, Zabriskie NA, Crandall AS, et al. Visual complaints associated with the AcrySof acrylic intraocular lens. J Cataract Refract Surg 2000;26(9):133945.

[10] Nanavaty MA, Spalton DJ, Boyce J, et al. Edge profile of co mmercially available square-edged intraocular lenses. J Cataract Refract Surg 2008;34(4):677-86.

[11] Heatley CJ, Spalton DJ, Kumar A, et al. Comparison of posterior capsule opacification rates between hydrophilic and hydrophobic single-piece acrylic intraocular lenses. J Cataract Refract Surg 2005;31(4):718-24.

[12] Findl O, Menapace R, Sacu S, et al. Effect of optic material on posterior capsule opacification in intraocular lenses with sharp-edge optics: randomized clinical trial. Ophthalmology 2005;112(1):67-72.

[13] Hollick J, Spalton J, Ursell G, et al. Lens epithelial cell regression on the posterior capsule with different intraocular lens materials. $\mathrm{Br} \mathrm{J}$ Ophthalmol 1998;82(10):1182-8.

[14] Hansen TE, Otland N, Corydon L. Posterior capsule fibrosis and intraocular lens design. J Cataract Refract Surg 1988;14(4):383-6.

[15] Nagata T, Watanabe I. Optic sharp edge or convexity: comparison of effects on posterior capsular opacification. Jpn J Ophthalmol 1996;40(3):397-403.

[16] Kim MJ, Lee HY, Joo CK. Posterior capsule opacification in eyes with a silicone or poly (methyl methacrylate) intraocular lens. J Cataract Refract Surg 1999;25(2):2515.

[17] Nishi O, Nishi K, Mano C, et al. The inhibition of lens epithelial cell migration by a discontinuous capsular bend created by a band-shaped circular loop or a capsulebending ring. Ophthalmic Surg Lasers 1998;29(2):11925.

[18] Scaramuzza A, Fernado GT, Crayford BB. Posterior capsule opacification and lens epithelial cell layer formation: Hydroview hydrogel versus AcrySof acrylic intraocular lenses. Cataract Refract Surg 2001;27(7):1047-54.

[19] Spratt HAC, Khan Y, Claoue'C. PCO and Nd: YAG rates after centerflex IOL implantation: 30 month result. Presented in ASCRS congress, San Diego, California, USA 2004.

[20] Apple DJ, Solomon KD, Tetz MR, et al. Posterior capsule opacification. Surv Ophthalmol 1992;37(2):73-116.

[21] Wejde G, Kugelberg M, Zetterström C. Posterior capsule opacification: comparison of 3 intraocular lenses of different materials and design. J Cataract Refract Surg 2003;29(8):1556-9.

[22] Nishi O, Nishi K. Effect of the optic size of a single-piece acrylic intraocular lens on posterior capsule opacification. J Cataract Refract Surg 2003;29(2):348-53.

[23] Kim NJ, Lee JH. Effect of an acrylic posterior chamber intraocular lens on posterior capsule opacification in cataract patients with associated risk factors. J Cataract Refract Surg 2003;29(8):1575-8.

[24] Ando H, Ando N, Oshika T. Cumulative probability of neodymium: YAG laser posterior capsulotomy after phacoemulsification. J Cataract Refract Surg 2003;29(11):2148-54.

[25] Tan JC, Spalton DJ, Arden GB. Comparison of methods to assess visual impairment from glare and light scattering with posterior capsule opacification. J Cataract Refract Surg 1998;24(12):1626-31.

[26] Knighton RW, Slomovic AR, Parrish RK 2nd. Glare measurements before and after neodymium-YAG laser posterior capsulotomy. Am J Ophthalmol 1985;100(5):708-13.

[27] Leydolt C, Davidovic S, Sacu S, et al. Long-term effect of 1piece and 3-piece hydrophobic acrylic intraocular lens on posterior capsule opacification: a randomized trial. Ophthalmology 2007;114(9):1663-9.

[28] Bender LE, Nimsgern C, Jose R, et al. Effect of 1-piece and 3- piece AcrySof intraocular lenses on the development of posterior capsule opacification after cataract surgery. J Cataract Refract Surg 2004;30(4):786-9.

[29] Findl O, Drexler W, Menapace R, et al. Accurate determination of effective lens position and lens-capsule distance with 4 intraocular lenses. J Cataract Refract Surg 1998;24(8):1094-8.

[30] Amon M. Biocompatibility of intraocular lenses. J Cataract Refract Surg 2001;27(2):178-9.

[31] Nishi O, Nishi K, Imanishi M. Synthesis of interleukin-1 and prostaglandin E2 by lens epithelial cells of human cataracts. Br J Ophthalmol 1992;76(6):338-41.

[32] Hayashi K, Hayashi H. Posterior capsule opacification after implantation of a hydrogel intraocular lens. $\mathrm{Br} \mathrm{J}$ Ophthalmol 2004;88(2):182-5.

[33] Abela-Formanek C, Amon M, Schild G, et al. Uveal and capsular biocompatibility of hydrophilic acrylic, hydrophobic acrylic and silicone intraocular lenses. J Cataract Refract Surg 2002;28(1):50-61.

[34] Vyas AV, Narendran R, Bacon PJ, et al. Three-hundred and Sixty degree barrier effect of a square-edged and an enhanced edge intraocular lens on centripetal lens epithelial cell migration two-year results. J Cataract Refract Surg 2007;33(1):81-7.

[35] Ram J, Pandey SK, Apple DJ, et al. Effect of in-the-bag intraocular lens fixation on the prevention of posterior capsule opacification. J Cataract Refract Surg 2001;27(7):1039-46. 